\title{
Effect of supplementation of $\beta$-carotene on nutrient intake, digestibility, milk yield and composition lactating crossbred cows
}

\author{
Vinod Bhateshwar, Dinesh Chandra Rai, Raj Kumar Duary, Aman Rathaur and Uday Pratap Singh
}

Received: 30 January 2021 / Accepted: 16 April 2021 / Published online: 27 July 2021

(C) Indian Dairy Association (India) 2021

\begin{abstract}
This study investigated the effect of supplementation of $\beta$-carotene on nutrient intake, digestibility, milk yield and composition lactating crossbred cows. Twenty four crossbred (Holstein $\times$ Sahiwal) cows with a close date of calving were divided into two homogeneous groups based on parity (4.62 \pm 0.46) and milk production level within the current lactation (8.57 $\pm 0.08 \mathrm{~kg}$ /day of mature equivalent milk). During the lactation period, the cows of the BETA-group were fed a diet supplemented with $500 \mathrm{mg} / \mathrm{cow} / \mathrm{d}$ of $\beta$-carotene. Compared to CONT-group (control), BETA-group ( $\beta$-carotene supplementation diet) failed to increase body weight, dry matter intake and digestibility of crude protein, crude fiber and nitrogen free-extract except ether extract and intake of total digestible nutrients which increased ( $p$ $<0.01$ ) in BETA-group. Overall daily milk yield, total milk yield, $3.5 \%$ fat-corrected milk, energy-corrected milk, fat yield, protein yield, lactose yield, solid not fat yield and total solids yield did not differ between two groups. No differences were observed in milk composition as fat $\%(3.36 \pm 0.03)$, protein $\%(3.08 \pm 0.04)$, lactose $\%(4.25 \pm 0.03)$, solid not fat $\%(7.48 \pm 0.03)$ and total solids \% $(10.80 \pm 0.05)$ between CONT and BETA-groups. Furthermore the somatic cell count was also not different the groups. The results of the present study demonstrated that supplementation of $\beta$-carotene has no significant benefits on productive parameters of lactating crossbred cows.
\end{abstract}

Department of Dairy Science and Food Technology, Institute of Agricultural Sciences, Banaras Hindu University, Varanasi-221 005, Uttar Pradesh India

Dinesh Chandra Rai $(\square)$

Department of Dairy Science and Food Technology, Institute of Agricultural Sciences, Banaras Hindu University, Varanasi-221 005, Uttar Pradesh, India

E-mail:dcrai@bhu.ac.in
Keywords: $\beta$-carotene, Crossbred cows, Dry matter intake, Milk components, Nutrient digestibility, Somatic cell count

\section{Introduction}

For the period of early time of lactation, whenever the energy requirement of the high producers lactate animal becomes increasingly difficult to meet out, nutrition, production and health of the animal are closely correlated with each other (Bisinotto et al. 2012). Maintenance of proper milk yield with better animal health is a difficult task for dairy cattle. So, increase in efficiency of yield of milk and its quality can be fulfilled along with complete nutrition and manage mental practices during the time between beginning and later lactation period (Singh et al. 2020).

Beta-carotene (BETA) associates with the family unit of carotenoids, phytochemical pigments generally synthesized in fruits, vegetables, plants, algae, and photosynthetic bacteria (Eggersdorfer and Wyss 2018). $\beta$-carotene is the principal natural precursor of vitamin $\mathrm{A}$ in bovine and it is mainly provided by green grass and legume forages (FAO, 2001). It is generally known that a good concentration of $\beta$-carotene is closely correlated with cattle health and production performance (Bilen and Mecitoglu 2021). Supplemental $\beta$-carotene may enhance growth, production, rumen function and digestive function (Karadas et al. 2005).

Domestic ruminants are mainly fed on like crop residue-based diets, which are low in minerals and vitamin contents (Khanum et al. 2007). In India the cattle and buffaloes are normally fed on crop residues straws and cultivated fodder that are low density and nutritive values feeds consist of mainly lignified cellulose and hemicellulose and have been traditionally used as a main feed ingredients (around 70-75\%) of ruminants diet (Kayastha et al. 2012). Ration fed to high yielding crossbred cows in India are generally deficient in minerals and vitamins A that are affecting animal productivity (Bhanderi and Garg 2012). It has been observed that the dietary level of certain vitamins and minerals necessary for body growth and production (NRC, 2001). Because based on tenth five year plan, government of India at present, the country faces a net deficit of $24.81 \%$ dry crop residues and $64.21 \%$ green fodder. The regional deficits are more essential 
than the national deficit, particularly for fodder, which is no way economical to transport very long distances. So addition of mineral-vitamin in animal diets can enhance the utilization of poor quality roughages mainly and improved the production performance. The aim of present study was a novel study on Indian crossbred cows with supplemental effect of $\beta$-carotene on nutrient intake, digestibility, milk yield and composition lactating crossbred cows.

\section{Materials and Methods}

\section{Animals and experimental diets}

The study was carried out at the dairy farm, Department of Dairy Science and Food Technology, Institute of Agricultural Sciences, Banaras Hindu University, Varanasi, on Indo Gangetic alluvial plain lands. Sahiwal crossbred (Holstein $\times$ Sahiwal) cows with a close date of calving were randomly located in individual pens to form two experimental groups: (i) Control (CONT; $\mathrm{n}=12$; parity $=$ $4.41 \pm 0.60$, milk yield $=8.53 \pm 0.12 \mathrm{~kg}$ ) and (ii) beta-carotene $(\mathrm{BETA} ; \mathrm{n}=12$; parity $=4.83 \pm 0.72 \mathrm{~kg}$, milk yield $=8.62 \pm 0.13 \mathrm{~kg}$ ), with similar body weight between treatment groups. The cows in group BETA were orally supplemented with $\beta$-carotene $(500 \mathrm{mg} /$ cow/d) during the entire experimental period of 30 days. During the digestible trial consisted of 23 days for diet adaptation and 7 days for sample collection. Samples of milk were collected at an interval of 15 days until 105 days postpartum, from 2 sequential milking of morning and evening, for measurements of milk yield and milk composition. The experimental groups received a basal diet twice daily containing wheat straw (Triticum aestivum) ad $l i b$ and green lucerne (Medicago sativa) as a green fodder in a mixed-ration, balanced to meet their nutrient requirements (NRC; Table 1). Both groups had free access to water and shaded areas. Diets for cows in both the groups were individually offered to each cow. The only difference in BETA intake between treatments was the $\beta$-carotene supply provided to the BETA-group thereby the effect to offer or not supplemental BETA in both treatment groups was assessed.

\section{Mineral-vitamin premix formulation}

A trace mineral-vitamin premix (DSM Nutritional Products India Pvt. Ltd., Mumbai, India) was formulated as shown in (Table 2). The mineral-vitamin premix level was designed to fulfill or exceed the mineral-vitamin requirements of lactating cows according to
DSM Mineral-Vitamin Supplementation Guidelines (2016) as well as NRC (2001).

\section{Intake and apparent digestibility evaluations}

Intake was evaluated daily by weighing the feed provided and the refusals recorded the next morning from each animal. Samples of the offered diets and the refusals were stored at $-20^{\circ} \mathrm{C}$ for further analysis and further analyzed to evaluate feed intake and digestibility. In 30 days experimental period (overall 7 samplings were taken during the experiment), samples of wheat straw, green lucerne, concentrate were collected on a daily basis. Samples were dried in an exceedingly forced-air oven at $60^{\circ} \mathrm{C}$ for $48 \mathrm{~h}$. Once dried, they were ground with a Wiley mill ( $2.0 \mathrm{~mm}$ screen) and analyzed in duplicates for dry matter (DM), crude protein (CP), crude fiber (CF), ether extract (EE) and ash according to the of the standard procedures of AOAC (2005). The total digestible nutrients (TDN) were estimated using the standard formula.

To determine the digestibility $(\mathrm{g} / \mathrm{kg})$ of each nutrient, the following equation was used:

Digestibility $(\mathrm{g} / \mathrm{kg})=[$ ingested nutrient amount $(\mathrm{g} / \mathrm{d})-$ amount nutrient extracted in the feces $(\mathrm{g} / \mathrm{d})] \times 1000$

[ingested nutrient amount $(\mathrm{g} / \mathrm{d})$ ]

Feces were collected every $24 \mathrm{~h}$ from each individual stall that was equipped with a metallic container with a mesh frame and sampled at $08: 00 \mathrm{~h}$ on the last 7 days of every period (06.00 AM; $02.00 \mathrm{PM}$ and $10.00 \mathrm{PM}$ ). A subsample of $10 \%$ was taken and stored at $-20^{\circ} \mathrm{C}$ until analysis.

Individual body weight (BW, $\mathrm{kg}$ ) and $\mathrm{BW}$ change (BWC, $\mathrm{kg} / \mathrm{d}$ ) were registered at the start and end of each experimental period. Dry matter intake (DMI, kg/d) was recorded on a daily basis but only data from the last 7 days were used for statistical analysis.

\section{Measurements of milk yield and milk components}

Cows were milked twice daily by hand milking and yields of milk were recorded automatically (Electric milk meters) and individual milk yields $(\mathrm{kg} / \mathrm{d})$ were recorded on a daily basis but only data from the last 15 days of each period were used for statistical analysis. Samples of milk were collected at an interval of 15 days until 105 days postpartum, from 2 sequential milking, morning and evening (4.00 A.M. and again at 4.00 P.M.). Individual milk

Table 1 Chemical composition of concentrate mixture, wheat straw and Lucerne

\begin{tabular}{lllc}
\hline & \multicolumn{1}{c}{ Diet } & Lucerne \\
\cline { 2 - 4 } Nutrient composition & Concentrate mixture & Wheat straw & 4.48 \\
Crude protein & 18.60 & 3.21 & 5.10 \\
Crude fiber & 9.78 & 36.40 & 1.04 \\
Ether extract & 3.45 & 1.12 & 5.39 \\
Nitrogen free-extract & 57.83 & 49.80 & 4.12 \\
Ash & 10.30 & 11.87 & \\
\hline
\end{tabular}


samples $(500 \mathrm{~mL})$ were collected on the last 15 days of each experimental period at 4.00 A.M. and again at 4.00 P.M using a volumetric milk meter. Milk samples were analyzed in duplicates by EKOMILK ultra milk analyzer (MILKANA KAM98-2A, EON TRADING, USA, made in Europe, Bulteh 2000 Ltd.) so as to work out fat, protein, lactose, solid not fat (SNF) and total solids (TS) and somatic cell count (SCC) using modified Olympus microscopic (CH20iBIMF, made in Olympus Pvt. Ltd. Nodia, India) and examined under the oil immersion lens (i NEA 100×/ 1.25 oil) at the department of dairy science and food technology laboratory.

Yields of milk corrected for 3.5\% fat and for energy were calculated according to NRC (2001) as follows:

$3.5 \%$ fat-corrected milk $\mathrm{g} / \mathrm{d}=(0.4324 \times$ milk yield $\mathrm{g} / \mathrm{d})+(16.218 \times$ milk fat yield $\mathrm{g} / \mathrm{d}$ )

Energy-corrected milk g/d $=[(0.3246 \times$ milk yield $\mathrm{g} / \mathrm{d})+(12.86 \times$ fat yield $\mathrm{g} / \mathrm{d})+(7.04 \times$ protein yield $\mathrm{g} / \mathrm{d})]$

Feed efficiency (FE) was calculated as: milk yield $(\mathrm{kg} / \mathrm{d}) \div$ DMI $(\mathrm{kg} / \mathrm{d})$

Adjusted FE was calculated as: 3.5\% FCM $(\mathrm{kg} / \mathrm{d}) \div \mathrm{DMI}(\mathrm{kg} / \mathrm{d})$

\section{Statistical analysis}

Data from the last 7 days of DMI, nutrient digestibility and fortnightly milk yield, milk components and SCC were considered for statistical analysis. Data were compared using the student's t-test procedure of the IBM SPSS statistics software package (2012). Variability in the data is expressed as the standard error of means. The probalility value $\mathrm{P}<0.01$ was considered for significance levels.

\section{Results and Discussion}

\section{Intake of nutrients}

The BW remained similar between CONT and BETA-groups (420 $\pm 9.94 \mathrm{~kg}$ ) (Table 3 ). A article stated that $\beta$-carotene supplementation had no effect on the average live weight or change of live weight during the trial duration (Ducker et al. 1984). Condron et al. (2014) obtained similar result of synthetic $\beta$ carotene had no effect on weight or gain compared nonsupplemented group of cows during experimental period. However, no differences were observed on cattle of the supplementation vitamin A in the feed intake, average daily gain, gain-to-feed ratio (Jo et al. 2020).

During the experimental period in both the groups of CONT and BETA cows had no effect on nutrients intake of DM (13.2 \pm 0.40 $\mathrm{kg} / \mathrm{d}), \mathrm{CP}(1.12 \pm 0.01 \mathrm{~kg} / \mathrm{d}), \mathrm{CF}(2.50 \pm 0.01 \mathrm{~kg} / \mathrm{d})$ and NFE $(5.66 \pm$ $0.03 \mathrm{~kg} / \mathrm{d}$ ). Adding $\beta$-carotene to BETA-group cows increased ( $p$
Table 2 Composition of the trace mineral-vitamin premix (unit/kg as-is basis)

\begin{tabular}{lc}
\hline Item & Quantity \\
\hline Vitamin A(MIU) & 2.000 \\
Vitamin D $(\mathrm{MIU})$ & 0.400 \\
Vitamin E $(\mathrm{g})$ & 20.000 \\
Biotin $(\mathrm{g})$ & 0.400 \\
Niacin $(\mathrm{g})$ & 10.000 \\
$\beta$-carotene $(\mathrm{g})$ & 10.000 \\
Iron $(\mathrm{g})$ & 12.000 \\
Copper $(\mathrm{g})$ & 4.000 \\
Manganese $(\mathrm{g})$ & 16.000 \\
Zinc $(\mathrm{g})$ & 16.000 \\
Magnesium $(\mathrm{g})$ & 80.000 \\
Cobalt $(\mathrm{g})$ & 0.400 \\
Iodine $(\mathrm{g})$ & 0.300 \\
Selenium $(\mathrm{g})$ & 0.120 \\
Chromium $(\mathrm{g})$ & 0.500 \\
Potassium $(\mathrm{g})$ & 5.000 \\
Sodium $(\mathrm{g})$ & 6.000 \\
\hline
\end{tabular}

$<0.01)$ nutrients intake of EE (0.24 vs. $0.33 \mathrm{~kg} / \mathrm{d})$ and TDN (6.14 vs. $6.69 \mathrm{~kg} / \mathrm{d}$ ) when compare with CONT-group cows (Table 3), which partly agrees with what was previously reported both in lactating cows (Michal et al.1994) when animals were fed with either $\beta$-carotene enriched premix mineral-vitamin. Condron et al. (2014) reported in similar way synthetic $\beta$-carotene failed to affect daily DMI, gain:feed, or days on feed on cattle.

\section{Digestibility of nutrients}

The apparent digestibility of nutrients in both the groups for DM, CP, CF and NFE was not different with the supplementation of $\beta$-carotene to cows (Table 3 ). Similar to our findings, there was no effects on apparent nutrients digestibility or utilization as observed by Dermauw et al. (2013) in zebu cattle. However animals fed with $\beta$-carotene had higher EE digestibility $(\mathrm{P}<0.01)$ when compared to the CONT group. Our results also corroborate with that of Nogueira et al. (2017) reporting greater digestibility of EE as well as Hino et al. (1993) reporting increased utilization of fatty acids on supplementation a combination of $\beta$-carotene and $\alpha$-tocopherol in the goat.

\section{Milk yield and milk components}

Data of daily milk yield 105 days of lactation of crossbred cows are presented in Fig. 1. Results revealed that daily milk yield was similar in BETA-group 5.66\% $(8.65 \mathrm{~kg} / \mathrm{d})$ at 15 days compared with CONT-group $5.62 \%(8.58 \mathrm{~kg} / \mathrm{d})$. The differences were found non-significant $(\mathrm{P}>0.05)$ among groups being at 90 days highest with BETA-group $6.72 \%$ (10.27 kg/d) and lowest with CONTgroup $6.53 \%(9.98 \mathrm{~kg} / \mathrm{d})$ and after 90 days lactation periods daily milk yield at 105 days slowly decrease in both groups. The overall 


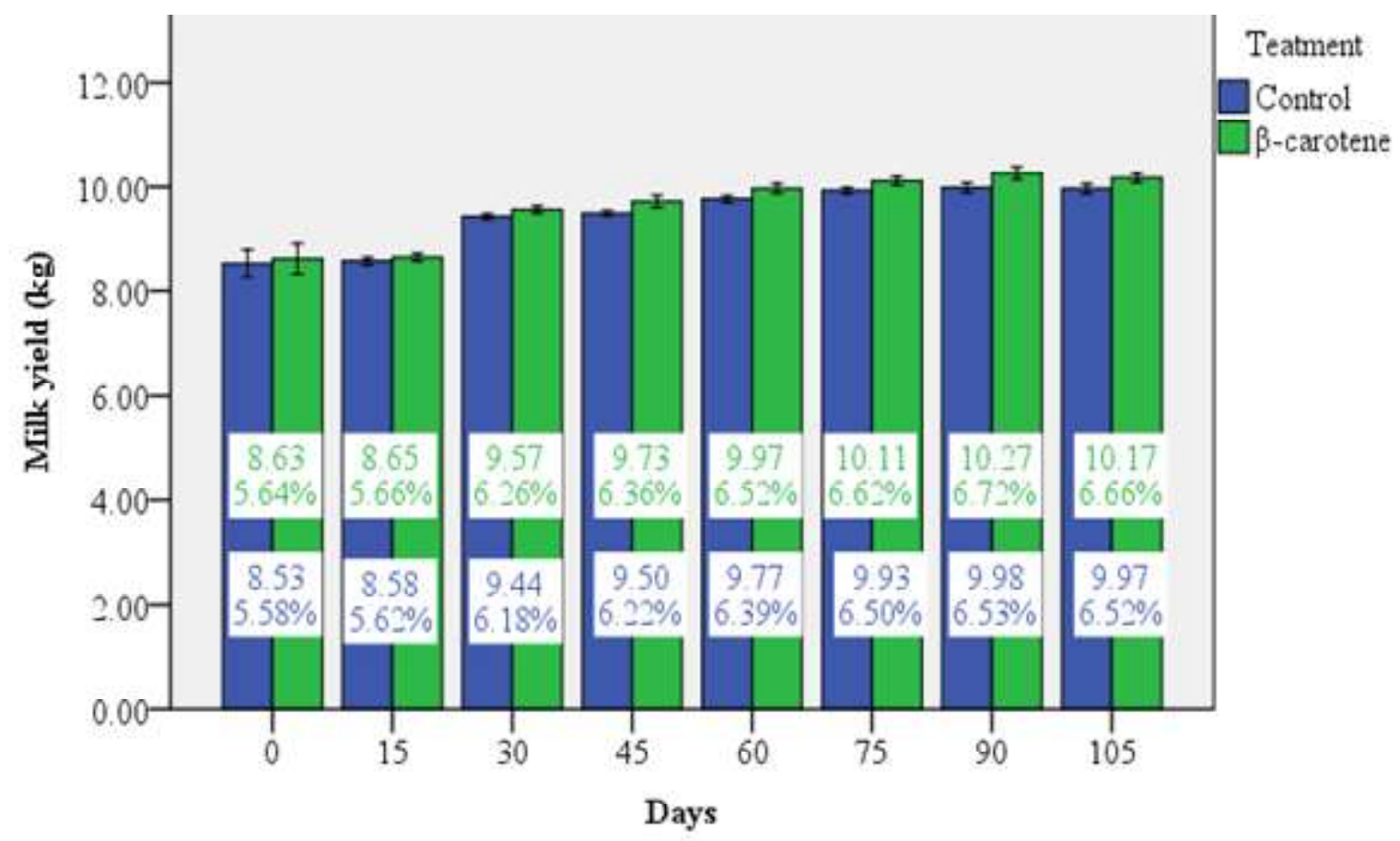

Fig. 1. Effect of supplementation of $\beta$-carotene on milk yield in crossbred cows

Table 3 Nutrient intake $(\mathrm{kg} / \mathrm{d})$ and digestibility in crossbred cows

\begin{tabular}{lllll}
\hline & CONT & BETA & SEM & P-value \\
\hline $\begin{array}{l}\text { Average body } \\
\text { weight }(\mathrm{kg})\end{array}$ & $419.2^{\mathrm{a}}$ & $421.2^{\mathrm{a}}$ & 9.94 & 0.92 \\
Intake $\mathrm{kg} / \mathrm{d}$ & & & \\
Dry matter & $12.9^{\mathrm{a}}$ & $13.5^{\mathrm{a}}$ & 0.40 & 0.47 \\
Concentrate intake & $5.15^{\mathrm{a}}$ & $5.51^{\mathrm{a}}$ & 0.17 & 0.32 \\
Wheat straw intake & $5.78^{\mathrm{a}}$ & $5.96^{\mathrm{a}}$ & 0.12 & 0.49 \\
Lucerne intake & $1.98^{\mathrm{a}}$ & $2.05^{\mathrm{a}}$ & 0.11 & 0.79 \\
Crude protein & $1.09^{\mathrm{a}}$ & $1.16^{\mathrm{a}}$ & 0.01 & 0.08 \\
Crude fiber & $2.47^{\mathrm{a}}$ & $2.54^{\mathrm{a}}$ & 0.01 & 0.21 \\
Ether extract & $0.24^{\mathrm{a}}$ & $0.33^{\mathrm{b}}$ & 0.01 & $<0.01$ \\
Nitrogen free-extract & $5.57^{\mathrm{a}}$ & $5.75^{\mathrm{a}}$ & 0.03 & 0.07 \\
Total digestible nutrients6.14 & $6.69^{\mathrm{b}}$ & 0.09 & $<0.01$ \\
Digestibility coefficient $(\mathrm{g} / \mathrm{kg})$ & & & 0.63 \\
Dry matter & $699^{\mathrm{a}}$ & $707^{\mathrm{a}}$ & 8.14 & 0.69 \\
Crude protein & $678^{\mathrm{a}}$ & $688^{\mathrm{a}}$ & 11.6 & 0.20 \\
Crude fiber & $530^{\mathrm{a}}$ & $552^{\mathrm{a}}$ & 8.34 & $<0.01$ \\
Ether extract & $641^{\mathrm{a}}$ & $796^{\mathrm{b}}$ & 40.13 & 0.64 \\
Nitrogen free-extract & $670^{\mathrm{a}}$ & $676^{\mathrm{a}}$ & 6.33 & \\
\hline
\end{tabular}

${ }^{a, b}$ Mean values for each experiment within a row with different superscript letters differ significantly $(\mathrm{p}<0.01)$. CONT $=$ Control group, $\mathrm{BETA}=\beta$-carotene supplemented group, $\mathrm{SEM}=$ standard error of mean, $\mathrm{TDN}=\% \mathrm{CP}(\mathrm{dig})+\% \mathrm{CF}(\mathrm{dig})+\% \mathrm{NFE}(\mathrm{dig})+\mathrm{EE}$ $(\mathrm{dig}) \times 2.25$

means in both groups for yields of milk, fat, protein, lactose, solid not fat and total solids were not affected (Table 4). Similar to our findings observed by De Ondarza et al. (2009) did not find changes in milk yield and its composition with supplementation of $\beta$-carotene in lactating dairy cows. The similar results finding of yields of milk and milk components yields values were increased non-significantly. However in cows the supplementation of carrot 
Table 4 Milk yield and quality indicators in crossbred cows

\begin{tabular}{|c|c|c|c|c|}
\hline & $\mathrm{CONT}^{4}$ & BETA $^{5}$ & SEM & P-value \\
\hline Milk yield, & $9464.05^{\mathrm{a}}$ & $9637.49^{\mathrm{a}}$ & 153.06 & 0.589 \\
\hline $3.5 \%$ Fat-corrected milk $^{1}, \mathrm{~g} / \mathrm{d}$ & $9215.70^{\mathrm{a}}$ & $9498.77^{\mathrm{a}}$ & 191.89 & 0.480 \\
\hline Energy-corrected milk ${ }^{2}, \mathrm{~g} / \mathrm{d}$ & $9158.60^{\mathrm{a}}$ & $9500.80^{\mathrm{a}}$ & 210.02 & 0.434 \\
\hline Feed efficiency ${ }^{3}$ & $0.73^{\mathrm{a}}$ & $0.71^{\mathrm{a}}$ & 0.01 & 0.408 \\
\hline \multicolumn{5}{|l|}{ Milk composition (\%) } \\
\hline Fat & $3.32^{\mathrm{a}}$ & $3.39^{\mathrm{a}}$ & 0.03 & 0.262 \\
\hline Protein & $3.02^{\mathrm{a}}$ & $3.14^{\mathrm{a}}$ & 0.04 & 0.178 \\
\hline Lactose & $4.18^{\mathrm{a}}$ & $4.31^{\mathrm{a}}$ & 0.03 & 0.095 \\
\hline Solid not fat & $7.46^{\mathrm{a}}$ & $7.50^{\mathrm{a}}$ & 0.03 & 0.516 \\
\hline Total solids & $10.79^{\mathrm{a}}$ & $10.82^{\mathrm{a}}$ & 0.05 & 0.802 \\
\hline \multicolumn{5}{|l|}{ Milk composition $(\mathrm{g} / \mathrm{d})$} \\
\hline Fat & $315.91^{\mathrm{a}}$ & $328.74^{\mathrm{a}}$ & 7.81 & 0.430 \\
\hline Protein & $287.49^{\mathrm{a}}$ & $304.66^{\mathrm{a}}$ & 8.70 & 0.341 \\
\hline Lactose & $397.35^{\mathrm{a}}$ & $419.89^{\mathrm{a}}$ & 9.61 & 0.326 \\
\hline Solid not fat & $707.17^{\mathrm{a}}$ & $724.03^{\mathrm{a}}$ & 14.05 & 0.567 \\
\hline Total solids & $1023.30^{\mathrm{a}}$ & $1032.55^{\mathrm{a}}$ & 21.79 & 0.840 \\
\hline $\begin{array}{l}\text { Somatic cell count }(\mathrm{Log} \\
\left.10^{4} \mathrm{cell} / \mathrm{mL}\right)\end{array}$ & $12.75^{\mathrm{a}}$ & $12.05^{\mathrm{a}}$ & 0.17 & 0.470 \\
\hline
\end{tabular}

${ }^{1} \mathrm{FCM}($ Fat corrected milk $-3.5 \%) \mathrm{g} / \mathrm{d}=(0.4324 \times$ milk yield $)+(16.218 \times$ milk fat yield $),($ NRC 2001 $),{ }^{2} \mathrm{ECM}($ Energy corrected milk $) \mathrm{g} /$ $\mathrm{d}=[(0.3246 \times$ milk yield $)+(12.86 \times$ fat yield $)+(7.04 \times$ protein yield $)]($ NRC 2001$),{ }^{3}$ Feed Efficiency $=$ Milk yield $(\mathrm{g} / \mathrm{d}) \div \mathrm{DMI}(\mathrm{g} / \mathrm{d})$, ${ }^{4} \mathrm{CONT}=$ Control group, ${ }^{5} \mathrm{BETA}=\beta$-carotene group

did not improved in the concentration of milk fat, protein, lactose and milk yield observed by Antone et al. (2015).

No differences were observed both group of cows in of $3.5 \%$ fatcorrected milk, energy-corrected milk, feed efficiency and nonsignificantly differ in milk composition during the experimental period (Table 4). Our results corroborate with that of De Ondarza and Engstrom (2009) the effect of supplementing $\beta$-carotene had no effect on $3.5 \%$ fat-corrected milk yield and its composition in dairy cows. In similar way no evidence was observed for positive responses to $\beta$-carotene supplementation in milk yield and milk composition between treatments in cows reported by (Kaewlamun et al. 2012; Oliveira et al. 2015). The similar result also found in goats by Gore and Lehloenya, (2020) that supplemental $\beta$-carotene did not significantly influence the average daily and total milk yield and milk composition.

\section{Somatic cell count}

The SSC was found non-significant in CONT-group (12.75 Log $10^{4} \mathrm{cell} / \mathrm{ml}$ of milk) than BETA-group (12.05 Log $10^{4} \mathrm{cell} / \mathrm{ml}$ of milk) those supplementation of $\beta$-carotene is show in (Table 4), which is similarly supported by Gore and Lehloenya (2020) the SCC did not differ significantly in $\beta$-carotene supplemented group than in non-supplemented group. Whereas on another hand a positively response observed by Kadyan et al. (2020) on buffaloes the effect of supplemented with $\beta$-carotene the overall milk SCC was significantly lower in $\beta$-carotene supplemented group as compared to that non-supplemented group.

\section{Conclusions}

Supplemental $\beta$-carotene significantly influence nutrients intake and digestibility of ether extract and total digestible nutrients of crossbred cows during postpartum period. Milk yield, composition and SCC did not differ significantly between $\beta$ carotene supplemented group and non-supplemented group. Further research is warranted on the supplemental effect of different levels of $\beta$-carotene on milk yield and composition and on concentration of $\beta$-carotene in blood plasma and milk at different stages of lactation in cows.

\section{Acknowledgments}

The authors are thankful to Head, Department of Dairy Science and Food Technology, Institute of Agricultural Sciences, Banaras Hindu University, Varanasi, India for providing guidance, infrastructure and necessary support to carry out the research work.

\section{References}

Antone U, Zagorska J, Sterna V, Jemeljanovs A, Berzins A, Ikauniece D (2015) Effects of dairy cow diet supplementation with carrots on milk composition, concentration of cow blood serum carotenes, and butter oil fat-soluble antioxidative substances. Agron Res 13: 879-891

AOAC (2005) Association of Official Analytical Chemists. Official Methods of Analysis. 18 $8^{\text {th }}$ ed., AOAC: Gaithersburg, MD, USA 
Bhanderi BM, Garg MR (2012) A study on reducing the incidence of subclinical and clinical mastitis in dairy cows by feeding a vitamins and minerals based strategic feed supplement. Indian J Dairy Sci 65:388392

Bilen EK, Mecitoglu GY (2021) Effects of Beta-carotene Administration on Fertility in Lactating Dairy Cows. Indian J Anim Res 55: 145149

Bisinotto RS, Greco LF, Ribeiro ES, Martinez N, Lima FS, Staples CR, Thatcher WW, Santos, JEP (2012) Influences of nutrition and metabolism on fertility of dairy cows. Anim Reprod 9: 260-272

Condron KN, Lemenager RP, Claeys MC, Lipkie TE, Schoonmaker JP (2014) Supplemental $\beta$-carotene I: Effect on plasma vitamin A, growth, performance, and carcass characteristics of feedlot cattle. J Meat Sci 98: 736-743

De Ondarza MB, Engstrom M (2009) Production and reproduction responses of dairy cows to supplemental $\beta$-carotene. Penn State Dairy Cattle Nutrition Workshop.

De Ondarza MB, Wilson JW, Engstrom M (2009) Case study effect of supplemental $\beta$-carotene on yield of milk and milk components and reproduction of dairy cows. Prof Anim Sci 25: 510-516

Dermauw V, Yisehak K, Dierenfeld ES, Du Laing G, Johan B, Wuyts B, Janssens GPJ (2013) Effects of trace element supplementation on apparent nutrient digestibility and utilisation in grass-fed zebu (Bos indicus) cattle. Livest Sci 155: 255-261

DSM Vitamin Supplementation Guidelines 2016 for Animal Nutrition. Available online: https://www.dsm.com/markets/anh/en_US/generic/ download-registration-vitamin supplementation-guidelines-inanimalnutrition 2016.html?assetPath=/content/dam/dsm/anh/ en_US/documents/Vitamin_Supp_Guidelin.pdf (accessed on 28 November 2019)

Ducker MJ, Yarrow NH, Bloomfield GA, Edwards-Weed JO (1984) The effect of $\beta$-carotene on the fertility of dairy heifers receiving maize silage. Anim Prod 39: 9-16

Eggersdorfer M, Wyss A (2018) Carotenoids in human nutrition and health. Arch Biochem Biophys 652: 18-26

FAO (2011) Rearing young ruminants on milk replacers and starter feeds. Animal Production and Health Manual Rome. 13: 19

Gore DLM, Lehloenya KC (2020) $\beta$-carotene supplementation does not improve milk yield and milk components of Saanen goats. Am J Anim Vet Sci 15: 123-128

Hino T, Andoh N, Ohgi H (1993) Effects of $\beta$-carotene and $\alpha$-tocopherol on rumen bacteria in the utilization of longchain fatty acids and cellulose. J Dairy Sci 76: 600-605
Jo YH, Peng DQ, Kim WS, Kim SJ, Kim NY, Kim SH, Nejad JG, Lee JS, Lee HG (2020) The effects of vitamin A supplementation during late-stage pregnancy on longissimus dorsi muscle tissue development, birth traits, and growth performance in postnatal Korean native calves. Asian-Australas J Anim Sci 33: 742-752

Kadyan S, Gulati HK, Kumar OS, Sihag S (2020) Effect of $\beta$-carotene supplementation on milk yield and its composition in Murrah buffaloes. Haryana Vet 59: 206-209

Kaewlamun W, Okouyi M, Humblot, P, Remy D, Techakumphu M, Duvauxponter C, Ponter AA (2012) Effects of a dietary supplement of $\beta$ carotene given during the dry period on milk production and circulating hormones and metabolites in dairy cows. Revue Med Vet 163: 235-241.

Karadas F, Pappas AC, Surai PF, Speake BK (2005) Embryonic development within carotenoid-enriched eggs influences the post-hatch carotenoid status of the chicken. Comp Biochem Physio. Part B, Biochemistry and Molecular Biology 14: 244-251

Kayastha TB, Dutta S, Kayastha, RB Deka RS (2012) Growth performance and nutrient utilization of growing calves with urea treated wheat straw based ration. Indian J Dairy Sci 65: 435-438

Khanum SA, Yaqoob T, Sadaf S, Hussain M, Jabbar MA, Hussain HN, Kausar R, Rehman S (2007) Nutritional evaluation of various feedstuffs for livestock production using in vitro gas method. Pakistan Vet J 27: 129-133

Michal JJ, Heirman LR, Wong TS, Chew BP (1994) Modulatory effects of dietary beta-carotene on blood and mammary leukocyte function in periparturient dairy cows. J Dairy Sci 77: 1408-1421

Nogueira RGS, Junior FP, Pereira ASC, Rodrigues, PHM (2019) Nutrient digestibility and changes in feeding behavior of cattle fed cottonseed and vitamin E. Sci Agric 76: 112-122

NRC (2001) Nutrient Requirements of Dairy Cattle: Seventh Revised Edition. Washington, DC: The National Academies Press. https:// doi.org/10.17226/9825

Oliveira RC, Guerreiro BM, Morais Junior NN, Araujo RL, Pereira RAN, Pereir MN (2015) Supplementation of prepartum dairy cows with $\beta$-carotene. J Dairy Sci 98: 6304-6314

Singh AK, Bhakat C, Kumari T, Mandal DK, Chatterjee A, Karunakaran M, Dutta TK (2020) Influence of pre and postpartum alphatocopherol supplementation on milk yield, milk quality, and udder health of Jersey crossbred cows at tropical lower Gangetic region. Vet World 13: 2006-2011 